\title{
Does the respondent's role affect the final value of management effectiveness? The case of Brazilian marine protected areas
}

\author{
Camila S. Brandão ${ }^{1 *}$, Wesley da Rocha ${ }^{2}$; Cleverson Zapelini ${ }^{3}$; Jessyca L. \\ Teixeira ${ }^{4}$ and Alexandre Schiavetti ${ }^{5}$
}

\begin{abstract}
Over the last decade, there has been a change in the way protected areas are managed across the world, as their management gradually ceases to be the sole responsibility of the government and is being shared with civil society. This study evaluates the management effectiveness, according to the managers and management boards of 20 marine protected areas (MPAs) on the coast of Brazil, using the Rapid Assessment and Prioritization of Protected Area Management (RAPPAM) methodology. There were differences in perspectives of the managers and management boards; 8 MPAs showed a significant difference in management effectiveness values, and 11 MPAs showed a change in management effectiveness category. In addition, there was a positive correlation between the year the management board was established, and the effectiveness value provided by the council, as well as a significant difference between the effectiveness values of the MPAs under federal and state responsibility. In view of these differences, it is suggested that evaluations of management effectiveness should be carried out not only with managers, but also with management boards to reduce possible incongruities caused by the responses of only one person.
\end{abstract}

Keywords: MPA; Management Board; RAPPAM; Environmental Policy; Coral Reef.

1 Programa em Desenvolvimento e Meio Ambiente - PPGDMA. Universidade Estadual de Santa Cruz, Salobrinho, Bahia, Brasil 45660-900.

2 Programa em Desenvolvimento e Meio Ambiente - PPGDMA. Departamento de Ciências Agrárias e Ambientais (DCAA). Universidade Estadual de Santa Cruz, Salobrinho, Bahia, Brasil 45660-900.

3 Ethnoconservation and Protected Areas Lab, Universidade Estadual de Santa Cruz, Salobrinho, Bahia, Brasil 45660-900.

4 Programa de Ecologia e Conservação da Biodiversidade - PPGECB. Universidade Estadual de Santa Cruz, Salobrinho, Bahia, Brasil 45660-900.

5 Ethnoconservation and Protected Areas Lab (LECAP), Departamento de Ciências Agrárias e Ambientais - Universidade Estadual de Santa Cruz, Brasil. Investigador Asociado CESIMAR, CENPAT, Puerto Madryn, Chubut, Argentina.

* Corresponding author $\bowtie$. E-mail address: CSB (milab_biologia@yahoo.com.br);JLT (jlsteixeira@uesc.br) 


\section{SIGNIFICANCE STATEMENT}

Risks of biased results were observed when considering only the manager testimonials to assess the effectiveness of the management of a protected area. We mitigated this situation by including in our analysis data from other members affected. This is the first study to assess the effectiveness of management from compiling the responses of the manager and also from the management board members, on a large scale, of the Brazilian coast. This approach distinguishes between previous studies that applied different methodologies, including RAPPAM, which only uses the manager's response. We found that in our new trial format, the risks of biased results were avoided. In this way, this study brings changes with updated and accurate results for the evaluation of the effectiveness of the management of a protected area.

\section{INTRODUCTION}

Brazil has more than $9,000 \mathrm{~km}$ of coastline with 463 cities, 17 coastal states and more than 50 million people living in coastal zones (Marroni and Asmus 2013). A significant part of the population depends directly or indirectly on resources captured from the marine environment (Vasconcellos et al. 2011). According to some authors, the establishment of marine protected areas (MPAs) can provide a great deal of protection against environmental degradation at the local level (Palumbi 2004; Mumby 2006; Babcock et al. 2010; Lubchenco and Grorud-Colvert 2015).

MPAs are defined, as "any area of intertidal or subtidal terrain, together with its overlying water and associated flora, fauna, historical and cultural features, which has been reserved by law or other effective means to protect part or all of the enclosed environment" (Kelleher 1999). In Brazil, protected areas (PAs) are denominated conservation units (CUs), and according to the National System of Conservation Units (SNUC), (Article 2 of Law No. 9,985 / 2000):

"A conservation unit is: Territorial space and its environmental resources, including jurisdictional waters, with relevant natural characteristics, legally instituted by the Government, with conservation objectives and defined limits, under a special administration regime, to which adequate protection guarantees are applied". (Brazil 2000)

Decree 4,340, of 2002, instituted two groups of CUs (those of Integral Protection and those of Sustainable Use), sub-divided into twelve categories. The percentage of protected areas in coastal and marine environments in Brazil and in the world has grown steadily, approaching the Aichi target 11, which aimed to protect at least $17 \%$ of land areas and $10 \%$ of continental waters in the period from 2011 to 2020 (Venter et al. 2014). About 236,200 sites around the world have achieved the protection of approximately $7 \%$ of the marine area under national jurisdiction (UNEP-WCMC and IUCN 2017). Studies have shown, however, that more than $40 \%$ of protected areas are poorly managed (Leverington et al. 2010).

Today, Brazil has a total of $7.65 \%$ of its protected areas in the Marine Biome, of which $23.13 \%$ are made up of Sustainable Use (SU) UCs (46.3\% at the state level, $36.11 \%$ at the national level) federal and $17.69 \%$ at the municipal level) (MMA 2020), most hectares of MPAs are classified as SU (Schiavetti et al. 2013). Sustainable use MPAs are a category that seeks to combine the presence of traditional communities with the conservation of biodiversity (Brazil 2000), allowing, in some cases, the extraction of natural resources. Many of these areas suffer from problems such as economic instability (Pinheiro et al. 2015; Fearnside 2016), the absence of a management plan, and a lack of basic infrastructure and staff to carry out surveillance and conservation actions (Gerhardinger et al. 2011).

Over the last decade, however, PA management has undergone changes, shifting from being the exclusive responsibility of the government to being shared either with members of civil society or with private actors (Borrini-Feyerabend et al. 2013). According to Berkes (1994), co-management can be defined as the division of decision-making responsibilities between natural resource users and government management authorities. Several PAs around the world are using this principle (Horigue et al. 2012; Weeks and Jupiter 2013; Vokou et al. 2014), mainly because community involvement can contribute to increased environmental awareness and consequently lead to a reduction in social conflicts (Campbell et al. 2013; Vasconcelos et al. 2013).

In Brazil, social participation in environmental management has been encouraged since 1981 by the National Environmental Policy (Brazil 1981). Other documents, such as the Federal Law for the creation of the National System of Conservation Units (SNUC, in Portuguese) (Brazil 2000) and the Federal Decree that established the National Plan for Protected Areas (Brazil 2006), enshrine the inclusion of society as a condition for PA management.

According to the SNUC, some PA categories must be managed through a management board and through a co-management system, and this council acts as a mediating instrument between the statesociety relationship through representation and participation of the population (Nobre et al. 2017; Gerhardinger et al. 2018). The management board 
of a PA is a collegial body formed by stakeholders, and functions as a democratic forum for valorization, discussion, negotiation and management of the area (Gerhardinger et al. 2018).

Also according to the SNUC, the management board may be advisory or deliberative. The deliberative council has the power to decide on certain issues involving PA management. The advisory council issues opinions that the manager can either accept or refuse, as the manager is responsible for connecting the social sectors directly related to the PA.

Based on the International Union for Conservation of Nature PA categories system, categories I (Strict Nature Reserve / Wilderness Area), II (National Park) and III (Natural Monument or Feature) must have an advisory council. On the other hand, IUCN category VI PAs (Habitat/Species management area) must have a deliberative council, and category V PAs (Protected Landscape/ Seascape) may have either an advisory board or a deliberative council, depending on the interests of the area (Brazil 2000).

Regardless of the function of the council, according to the SNUC, the council must be composed of members of public power and civil society, with these members being elected by each respective group and representing their group's interests in management of the MPA (IUCN 1994; Brazil 2000) in a partnership system. In this type of system, there is negotiation between the citizens and the holders of power, dividing decision making and planning into committees and giving decision-making power to the citizens (Arnstein 1969).

Regarding PAs, studies evaluating management effectiveness have proved essential in providing useful information and assisting managers and decision makers in identifying strengths and weaknesses (Day et al. 2012). Izurieta-Valery (1997) defines management effectiveness as the set of characteristics, capacities and competencies that allow a PA to satisfactorily fulfil the functions and objectives for which it was created. Such assessments offer opportunities to identify key factors that influence MPA management effectiveness, such as monitoring/research, human resources, investment, social participation, and conflicts between users and management (Oliveira-Júnior et al. 2016).

Among the methods to evaluate effectiveness, the Rapid Assessment and Prioritization of Protected Area Management (RAPPAM) tool (Ervin 2003a) is one of the most commonly accepted in the world, having been applied in more than 57 countries and 1,800 PAs (Ervin 2003b; Corral 2010; Lu et al. 2012; Hockings et al. 2015; Oliveira-Júnior et al. 2016). In Brazil, RAPPAM had been applied to 473 PAs under Federal and State management up to 2011 (Ogana et al. 2012).
The RAPPAM questionnaire was created based on the framework developed by the World Commission on Protected Areas, which covers all six elements of management: context, planning, inputs, processes, outputs, and outcomes (Hockings et al. 2000). However, the RAPPAM questionnaire presents certain limitations, as pointed out by Ervin (2003a), such as the methodology having been developed specifically for terrestrial PAs and requiring modifications to be applied to MPAs, as done by Corral (2010) and Brandão et al. (2017). In addition, the quality of the data depends on the willingness and participation of PA managers and on transparency in the provision of said information, assuming that managers have the appropriate knowledge to provide reliable data.

Faria (2007) suggests inserting questions in the RAPPAM questionnaire addressing elements that assess the inter-relationships between environmental and human factors, in addition to the ability to understand the objectives intrinsic to the PA. The RAPPAM methodology is applied through interviews or by email / site and is a tool made up of easy-tounderstand questions with a guide that explains the purpose of each question (Ervin 2003a).

It is worth mentioning that since its inception, RAPPAM has always been used to evaluate management effectiveness, based only on the perspective of the manager (Goodman 2003; Almeida et al. 2016), disregarding the existence of other members involved in PA management. This same reality has been observed in the management effectiveness evaluations carried out in Brazil, wherein only the managers' responses were used to determine the effectiveness value for the area, thereby disregarding the existence of the management board (Santos and Schiavetti 2014; Almeida et al. 2016; Araújo and Bernard 2016).

Using the RAPPAM approach, this study evaluated the management effectiveness of 20 Brazilian MPAs with active management boards. The responses were analyzed based on the knowledge of the managers and the management boards to verify whether there are differences between the effectiveness scenarios provided by the two agents of MPA management.

\section{MATERIAL AND METHODS}

MPA selection was based on 18 priority areas for conservation, as indicated by the National Action Plan for Conservation of Coral Reefs (PAN Corals) (Castro et al. 2016). A total of 37 MPAs with reef environments were found in these priority areas, this being the total number of MPAs contacted for the research.

Before starting the research, authorization was obtained from the body responsible for the management 
of federal MPAs, the Biodiversity Authorization and Information System (SISBIO n⿳0 45079-8). For state MPAs, authorizations were obtained from Rio Grande do Norte (Institute for Sustainable Development and Environment $n^{\mathrm{O}}$ 002/2016), Rio de Janeiro (State Institute for the Environment $\left.\mathrm{n}^{\mathrm{O}} 21 / 2015\right)$, and São Paulo (Forestry Institute $\mathrm{n}^{\mathrm{O}} 456 / 2015$ ).

Initial contact was made with the managers and members of the management boards to explain the research methodology and to provide the link to the questionnaire using Google surveys. Data were collected between April 2015 and September 2016. The RAPPAM questionnaire link was emailed to the managers and management boards. Given the difficulty obtaining more responses from the members of the management boards, the selection of respondents was made according to the existing groups and limited to one respondent representing public power and one respondent representing civil society, totaling three interviewees for each MPA.

When the respondents did not answer all the questions, they were forwarded another email. If the respondents did not have the knowledge and/or information to answer a given question, the question was withdrawn from the final score of the modules. Given the low number of blank responses, this did not affect the final result of the survey.

Of the 37 MPAs, 17 did not respond or the management board was not operational. Therefore, a total of 20 MPAs were analyzed (Table 1 and Figure 1), five of which had only the manager and one member of the management board responding (MPA5, MPA9, MPA11, MPA17 and MPA18), due to difficulty obtaining responses from the other members.

Among the 20 MPAs surveyed, 11 are managed at Federal level, eight at State level, and one at Municipal level. Regarding the management category, 11 MPAs are categorized as integral protection (IUCN categories Ia, II and III), and nine are categorized as sustainable use (IUCN categories IV, V and VI) (Table 1).

The RAPPAM questionnaire used in this research underwent certain modifications to be applied to MPAs, such as the inclusion of questions for the analysis of coastal and marine environments, and questions related to climate change, as proposed by Ervin and Belokurov (2010) (Table 1).

The RAPPAM questions have four response options, with scores varying from 0 to 3 . The actual scores as a percentage of the potential score of the module was used to obtain the effectiveness value for each module. The mean of the 14 modules of the questionnaire (Goals-Results) was used to determine MPA management effectiveness (Table 1).

To obtain the management effectiveness value of the MPAs that had two responses from their management boards, the two answers were averaged for each of the modules, with the management effectiveness value being obtained through the mean values of these modules. For the five MPA that had only one response from the management boards, the single value was used to determine the management effectiveness of the management boards.

Each management effectiveness value obtained for the manager and management board in each MPA was compared to standard values $(<40 \%$ - low level, $40-60 \%$ - medium level, $>60 \%$ - high level) (Ervin 2003a) to define the category in which each MPA is located.

Table 2 summarizes the statistical analyses carried out in this research. The 20 MPAs were used for all the analyses, with the exception of those involving the management levels. These analyses were performed using generalized linear model (GLM). A residual analysis was performed to verify the adequacy of the data to the chosen probability distribution, such as the distribution of errors for all models using the RT4Bio package and rdiagnostic procedure (Crawley 2013). The model was adjusted with Gaussian error distribution. Contrast analysis was used to group explanatory variables that did not differ significantly from one another $(p>0.05)$ (Crawley 2013). If the level of aggregation was not significant and did not alter the deviance explained by the null model, the levels were pooled together (contrast analysis).

A comparison was made between the categories of management effectiveness obtained for the manager and management board of each individual MPA. In addition, the MPAs were classified in terms of the type of management board (advisory and deliberative); the mean and relative standard deviation (RSD) were analyzed and a t-test was performed to check for differences between the two types of councils.

Finally, the mean and RSD were obtained from the effectiveness value provided by the managers and the management boards to verify the management value for the MPAs considering both responses. All statistical analyses were performed using $\mathrm{R}$ software ( $\mathrm{R}$ Development Team 2016). 
Table 1. Marine protected areas, with acronyms, IUCN category, year of creation of the MPA (Year), year of creation of the management board (Year MB), category of protection (IP - Integral Protection; SU - Sustainable Use), management level (F - Federal, S - State, M - Municipal), type of management board (A - Advisory, D - Deliberative), and number persons on the management board that answered the questionnaire.

\begin{tabular}{|c|c|c|c|c|c|c|c|c|}
\hline Marine protected areas & Acronym & IUCN & Year & Year MB & Category & Level & $\begin{array}{c}\text { Type of } \\
\text { board }\end{array}$ & $\begin{array}{c}\text { Number of } \\
\text { answered }\end{array}$ \\
\hline Parque Estadual Marinho da Pedra do Risca do Meio & MPA1 & II & 1997 & 2015 & IP & $\overline{\mathrm{S}}$ & $\mathrm{A}$ & 2 \\
\hline Área de Proteção Ambiental Estadual dos Recifes de Corais & MPA2 & $\mathrm{V}$ & 2001 & 2011 & $\mathrm{SU}$ & $\mathrm{S}$ & $\mathrm{D}$ & 2 \\
\hline Área de Proteção Ambiental Fernando de Noronha & MPA3 & $\mathrm{V}$ & 1986 & 2002 & SU & $\mathrm{F}$ & $\mathrm{D}$ & 2 \\
\hline Área de Proteção Ambiental Costa dos Corais & MPA4 & $\mathrm{V}$ & 1997 & 2011 & $\mathrm{SU}$ & $\mathrm{F}$ & $\mathrm{D}$ & 2 \\
\hline Parque Natural Marinho de Recife de Fora & MPA5 & II & 1997 & 1997 & IP & M & $D^{*}$ & 1 \\
\hline Reserva Extrativista Corumbau & MPA6 & VI & 2000 & 2002 & $\mathrm{SU}$ & $\mathrm{F}$ & $\mathrm{D}$ & 2 \\
\hline Parque Nacional Marinho dos Abrolhos & MPA7 & II & 1983 & 2002 & IP & $\mathrm{F}$ & $\mathrm{A}$ & 2 \\
\hline Reserva Extrativista de Cassurubá & MPA8 & VI & 2009 & 2012 & $\mathrm{SU}$ & $\mathrm{F}$ & $\mathrm{D}$ & 2 \\
\hline Área de Proteção Ambiental Estadual do Pau Brasil & MPA9 & $\mathrm{V}$ & 2002 & 2002 & $\mathrm{SU}$ & $\mathrm{S}$ & $\mathrm{D}$ & 1 \\
\hline Parque Estadual da Costa do Sol & MPA10 & II & 2011 & 2011 & $\mathrm{PI}$ & $\mathrm{S}$ & $\mathrm{A}$ & 2 \\
\hline Reserva Extrativista Marinha de Arraial do Cabo & MPA11 & VI & 1997 & 2010 & $\mathrm{SU}$ & $\mathrm{F}$ & $\mathrm{D}$ & 1 \\
\hline Monumento Natural do Arquipélago das Ilhas Cagarras & MPA12 & III & 1989 & 2010 & IP & $\mathrm{F}$ & $\mathrm{A}$ & 2 \\
\hline Reserva do Desenvolvimento Sustentável do Aventureiro & MPA13 & VI & 2014 & 2014 & $\mathrm{SU}$ & $\mathrm{S}$ & $\mathrm{D}$ & 2 \\
\hline Estação Ecológica Tupinambás & MPA14 & Ia & 1987 & 2006 & IP & $\mathrm{F}$ & $\mathrm{A}$ & 2 \\
\hline Parque Estadual Xixová-Japui & MPA15 & II & 1993 & 2009 & IP & $\mathrm{S}$ & $\mathrm{A}$ & 2 \\
\hline Parque Estadual Marinho de Laje de Santos & MPA16 & II & 1993 & 2009 & IP & $\mathrm{S}$ & $\mathrm{A}$ & 2 \\
\hline Área de Proteção Ambiental Marinha do Litoral Centro & MPA17 & $\mathrm{V}$ & 2008 & 2008 & $\mathrm{SU}$ & $\mathrm{F}$ & $\mathrm{D}$ & 1 \\
\hline Estação Ecológica Federal dos Tupiniquins & MPA18 & Ia & 1986 & 2012 & IP & $\mathrm{F}$ & $\mathrm{A}$ & 1 \\
\hline Parque Estadual Acarai & MPA19 & II & 2005 & 2006 & IP & $\mathrm{S}$ & $\mathrm{A}$ & 2 \\
\hline Reserva Biológica Marinha do Arvoredo & MPA20 & $\mathrm{Ia}$ & 1990 & 2004 & IP & $\mathrm{F}$ & $\mathrm{A}$ & 2 \\
\hline
\end{tabular}

$* \overline{\overline{T h e} \text { municipal management board has advisory and deliberative action. However, for the purposes of this research, the management board will be considered as }}$ deliberative.

**Source of data: Observatory for Protected Areas of the WWF. Available in http://observatorio.wwf.org.br/unidades/ 


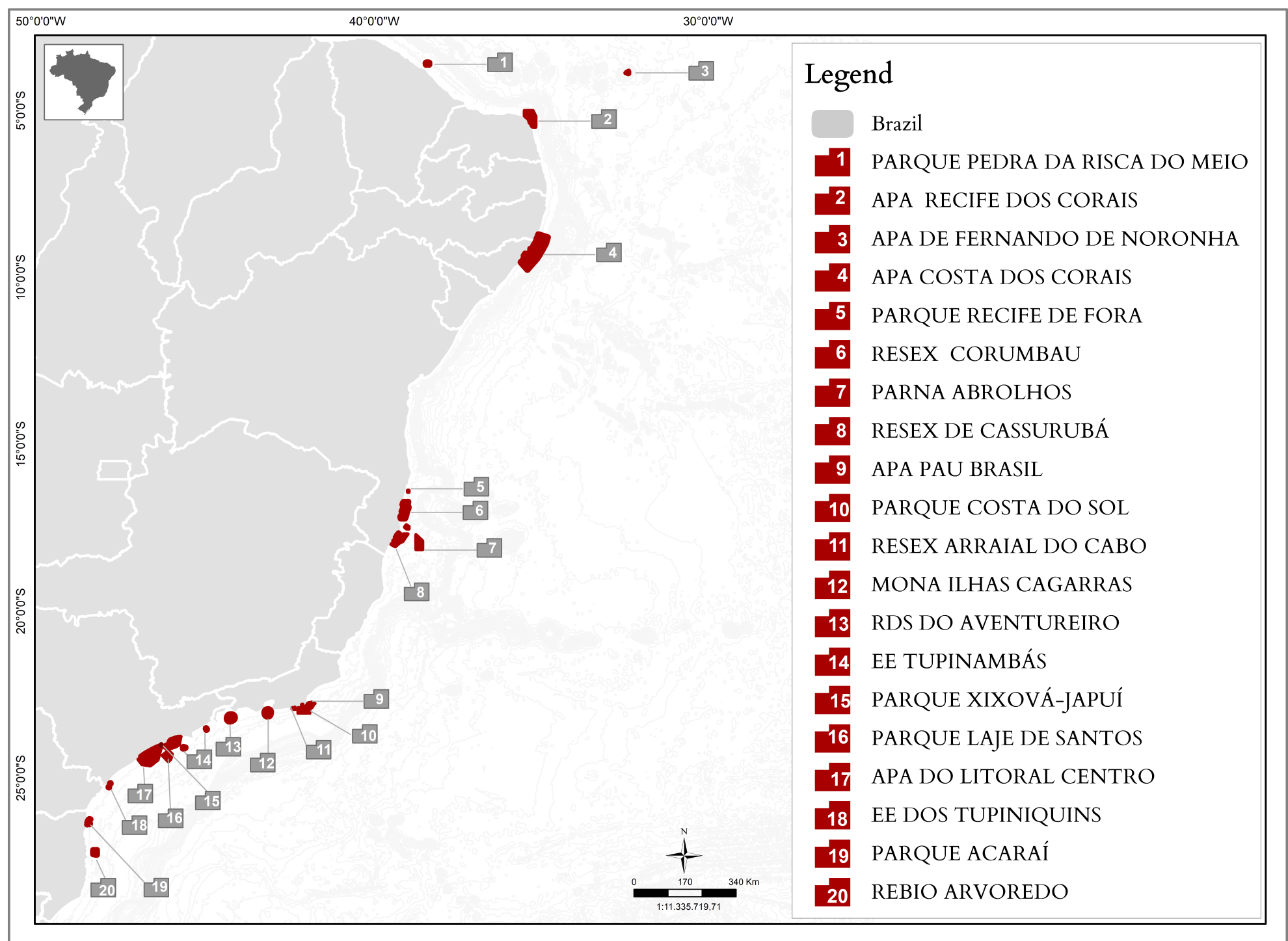

Figure 1. Marine Protected Areas of the Brazilian coast that participated in the RAPPAM assessment on management effectiveness. 
Table 2. Statistical analyses performed for the Marine Protected Areas on the Brazilian coast. Types of variables: explanatory (VE) and response (VR); Interviewee: Manager (M) and Management Board (MB).

\begin{tabular}{|c|c|}
\hline Questions & Variables \\
\hline What is the effect of the responses between Manager and Management & VE: Respondent (M or MB) \\
\hline Board on the obtained management effectiveness values? & VR: Management effectiveness \\
\hline What is the effect of the responses between Manager and Management & VE: Respondent (M or MB) \\
\hline Board on the values of the management effectiveness modules? & VR: 14 questionnaire modules \\
\hline $\begin{array}{l}\text { What is the effect of the number of respondents in the Management } \\
\text { Board ( } 1 \text { or } 2 \text { ) on the management effectiveness value? }\end{array}$ & $\begin{array}{l}\text { VE: } \text { MPA with } 1 \text { response from the } \mathrm{MB} \text { and } \mathrm{M}(\mathrm{n}=5 \mathrm{MPA}) \\
\text { and } 2 \text { responses from the MB and } \mathrm{M}(\mathrm{n}=15 \mathrm{MPA}) \\
\text { VR: Management effectiveness }\end{array}$ \\
\hline $\begin{array}{l}\text { What is the effect of the number of respondents in the Management } \\
\text { Board ( } 1 \text { or } 2 \text { ) on the values of the management effectiveness modules? }\end{array}$ & $\begin{array}{l}\text { VE: } \mathrm{MPA} \text { with } 1 \text { response from the } \mathrm{MB} \text { and } \mathrm{M}(\mathrm{n}=5 \mathrm{MPA}) \\
\text { and } 2 \text { responses from the } \mathrm{MB} \text { and } \mathrm{M}(\mathrm{n}=15 \mathrm{MPA}) \\
\text { VR: } 14 \text { questionnaire modules }\end{array}$ \\
\hline $\begin{array}{l}\text { What is the effect of the management level, time in the position, } \\
\text { category of protection and year of creation of the } \\
\text { MPA on the management effectiveness value from the Manager? }\end{array}$ & $\begin{array}{l}\text { VE: Management level (Federal and State), time in the position, } \\
\text { category of protection and year of creation of the MPA of the Manager. } \\
\text { VR: Management effectiveness }\end{array}$ \\
\hline $\begin{array}{l}\text { What is the effect of the time of creation, time in the position and } \\
\text { management level on the management effectiveness value provided } \\
\text { by the Management Board? }\end{array}$ & $\begin{array}{l}\text { VE: Time of operation, time in the position and management level } \\
\text { (Federal and State) of the Management Board. } \\
\text { VR: Management effectiveness }\end{array}$ \\
\hline
\end{tabular}




\section{RESULTS}

According to the managers' responses, six MPAs showed high effectiveness $(>60 \%)$, with MPA8 showing the highest value, and six MPA showed low effectiveness $(<40 \%)$, with MPA17 showing the lowest value (Figure 2). On the other hand, when analyzing management effectiveness according to the members of the management boards, none of the 20 MPAs were considered to be highly effective, with the highest value being observed for MPA18 (58.8\%), and five MPA showing low effectiveness, with the lowest value observed for MPA13 (Figure 2).

This absence of a standard in the management effectiveness responses provided by the managers and the management boards can be better analyzed when comparing the effectiveness categories for the 20 MPAs. As such, 11 MPAs presented a change between categories (from high to medium or from medium to low), eight of which showed the highest effectiveness value for the manager and three showing the highest effectiveness value for the management board (Figure 2 ). Grouping these $11 \mathrm{MPAs}$ with a changed category according to the type of management board, it was found that three MPAs have advisory management boards (MPA1, MPA12 and MPA16) and eight MPAs have deliberative management boards (MPA2, MPA3, MPA4, MPA5, MPA8, MPA9, MPA13 and MPA17) (Table 1 and Figure 2).

Through GLM, eight MPA showed a significant difference between the management effectiveness values provided by managers, in comparison to those provided by management boards (Table 3 , Figure 2). Among these eight MPAs, two have advisory management boards (MPA1 and MPA14), and six have deliberative management boards (MPA2, MPA4, MPA8, MPA9, MPA13 and MPA17) (Table 1 and Figure 3).

However, when evaluating management effectiveness according to the types of management boards, a significant difference was not found $(t-$ test $: 21.29$ $t=0,382, d f=191 p>0.05)$ between mean effectiveness for the advisory and deliberative management boards (mean $=47.1$ and $45.1+R S D=19.8$ and 22.5, respectively).

According to the GLM of the 14 modules that compose the management effectiveness values provided by managers, in comparison to values provided by management boards, it was observed that only the Research, Assessment, and Monitoring modules presented significant differences (Deviance $2,36=$ $2124.88, p=0.04$ ), with none of the other modules differing between managers and management boards $(p>0.05)$.

In turn, when comparing management effectiveness from the manager's perspective with that of the management board, no significant differences were ob- served between the effectiveness values for the five MPAs that had only one response from the council, compared with the effectiveness values for the 15 MPAs with two answers from the council (Deviance $3,36=510.47, p=0.4)$. A significant difference between the two groups of MPAs was not found when comparing the 14 modules that compose effectiveness as a variable response $(p>0.05)$.

Considering the answers of the management boards, a difference was observed when the effectiveness value was separated between the management levels of 19 of the analyzed MPAs, with the federal level showing a higher effectiveness value in comparison to the state level (Table 4). In addition, a positive correlation was observed between management effectiveness of the management boards and the time since their creation, indicating that the older the council, the greater the MPA management effectiveness value. However, no differences were observed in management effectiveness in relation to the management board's time in the position (Table 4).

When analyzing the mean between managers and management boards, it was observed that no MPA presented a high effectiveness value, and eight showed a low effectiveness value (Figure 3 ). In addition, when calculating the mean of the 20 MPAs with management effectiveness values for managers and management boards, a mean value of $46.0(R S D=20.2)$ was found.

\section{DISCUSSION}

When calculating mean management effectiveness values provided by the managers and the management boards, a difference was found in comparison to the model that has been used for PAs in Brazil and the rest of the world (Ervin 2003b; Veenvliet and Sovinc 2009; Corral 2010; Lu et al. 2012; Ogana et al. 2012; Araújo and Bernard 2016; Brandão et al. 2017). In this model, effectiveness is based only on the evaluations given from managers' perspectives.

It was observed that management effectiveness values provided by the managers and the management boards presented very close mean values for the $20 \mathrm{MPAs}$ analyzed herein $($ mean $=47.2 R S D=33.1$ for the managers; mean $=46.1 R S D=20.7$ for the management boards), although different values were shown for the individual MPAs (Figure 2). From the management board's perspective, all Brazilian MPAs still require improvements to achieve the protection objectives for which they were created, especially in Results (whether actions in the last two years were consistent with the MPA) and Inputs (addressing infrastructure, employees, financial resources and communication).

This category of mean management effectiveness 

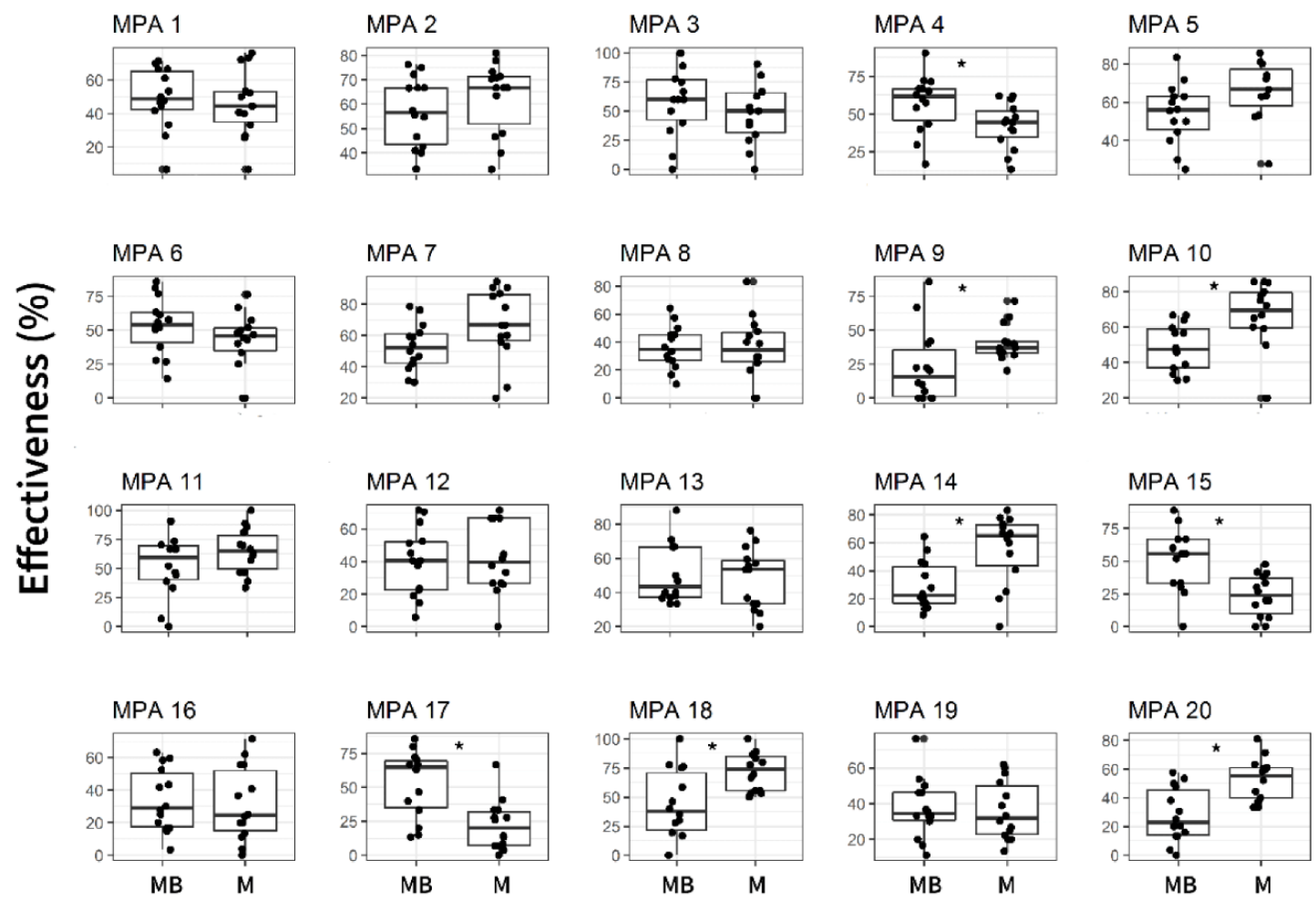

Figure 2. Boxplots, indicating minimum, maximum, median, lower and upper quartiles of the modules that form management effectiveness (\%) from the management board (MB) and manager (M) perspectives for the 20 marine protected areas. *Statistical differences.

has also been found in other PAs around the world, as observed by Lu et al. (2012), who found a mean effectiveness value of $55 \%$ when studying five PAs in Taiwan, and Corral (2010), who, in turn, identified a mean value of $57.4 \%$ in seven MPAs in Spain. In addition, when analyzing mean management effectiveness of MPAs in Brazil, Ogana et al. (2012) found a value of $49.3 \%$ for 40 marine and coastal PAs, and only Brandão et al. (2017), working with 11 MPAs within reef environments, found a high effectiveness value in $2015(60.0 \%)$.

Through analysis of effectiveness in the work of Brandão et al. (2017), on 11 MPAs over 10 years, it was observed that Inputs was the biggest contributor to reductions in management effectiveness values. According to the authors, this shows a problem between the structuring of the MPA and its capacity to develop protection functions, without human resources, financial resources and infrastructure. Other studies have also shown that Inputs were responsible for reducing the effectiveness value in PAs (Goodman 2003; Corral 2010; Gerhardinger et al. 2011; Lu et al. 2012; Magris et al. 2013). Leverington et al. (2010) also highlight that these low scores on questions about financial and human resources are a global standard for
PAs, whether marine or terrestrial.

Oliveira Júnior et al. (2016), working on MPAs in Brazil, identified five variables as the most important for good management (higher levels of monitoring / research; higher investment; greater human resources; greater social participation, and; lower levels of conflict between users and managers). Analyzing these variables according to the mean of the managers' responses and the mean of the management board, no significant difference was found between them. However, the responses of the managers maintained a higher mean value than the responses of the management board, especially on variables whose questions more directly address the relationship of the MPA with the population, such as questions on human resources, the existence of conflicts and social participation.

When comparing management effectiveness from the perspectives of the managers and management boards, both were expected to report similar values for the same MPA, especially among the nine MPAs with deliberative management boards. This was expected because, according to Federal Decree 4.340/02, it is necessary to hold public meetings to discuss problems and possible solutions for the co-management of 
Table 3. Generalized linear models (Gaussian Error Distribution) built with the response of management effectiveness among the respondents (manager and management board) for the 20 marine protected areas. *Marine protected area that showed significant difference in management effectiveness between the manager and the management board.

\begin{tabular}{cccc}
\hline \hline MPA & df & Deviance/F & P \\
\hline MPA1 & 1 & 2099.4 & $0.04^{*}$ \\
MPA2 & 1 & 4890.6 & $0.003^{*}$ \\
MPA3 & 1 & 237.51 & 0.3 \\
MPA4 & 1 & 1765.7 & $0.03^{*}$ \\
MPA5 & 1 & 946.57 & 0.2 \\
MPA6 & 1 & 61.21 & 0.6 \\
MPA7 & 1 & 79.56 & 0.6 \\
MPA8 & 1 & 5834.9 & $0.004^{*}$ \\
MPA9 & 1 & 4703.9 & $0.002^{*}$ \\
MPA10 & 1 & 10.62 & 0.8 \\
MPA11 & 1 & 54.04 & 0.7 \\
MPA12 & 1 & 771.5 & 0.1 \\
MPA13 & 1 & 4274.3 & $<0.001^{*}$ \\
MPA14 & 1 & 1505.3 & $0.03^{*}$ \\
MPA15 & 1 & 2.31 & 0.9 \\
MPA16 & 1 & 1358.0 & 0.07 \\
MPA17 & 1 & 6625.1 & $<0.001^{*}$ \\
MPA18 & 1 & 856.93 & 0.3 \\
MPA19 & 1 & 40.44 & 0.7 \\
MPA20 & 1 & 904.6 & 0.2 \\
\hline \hline
\end{tabular}

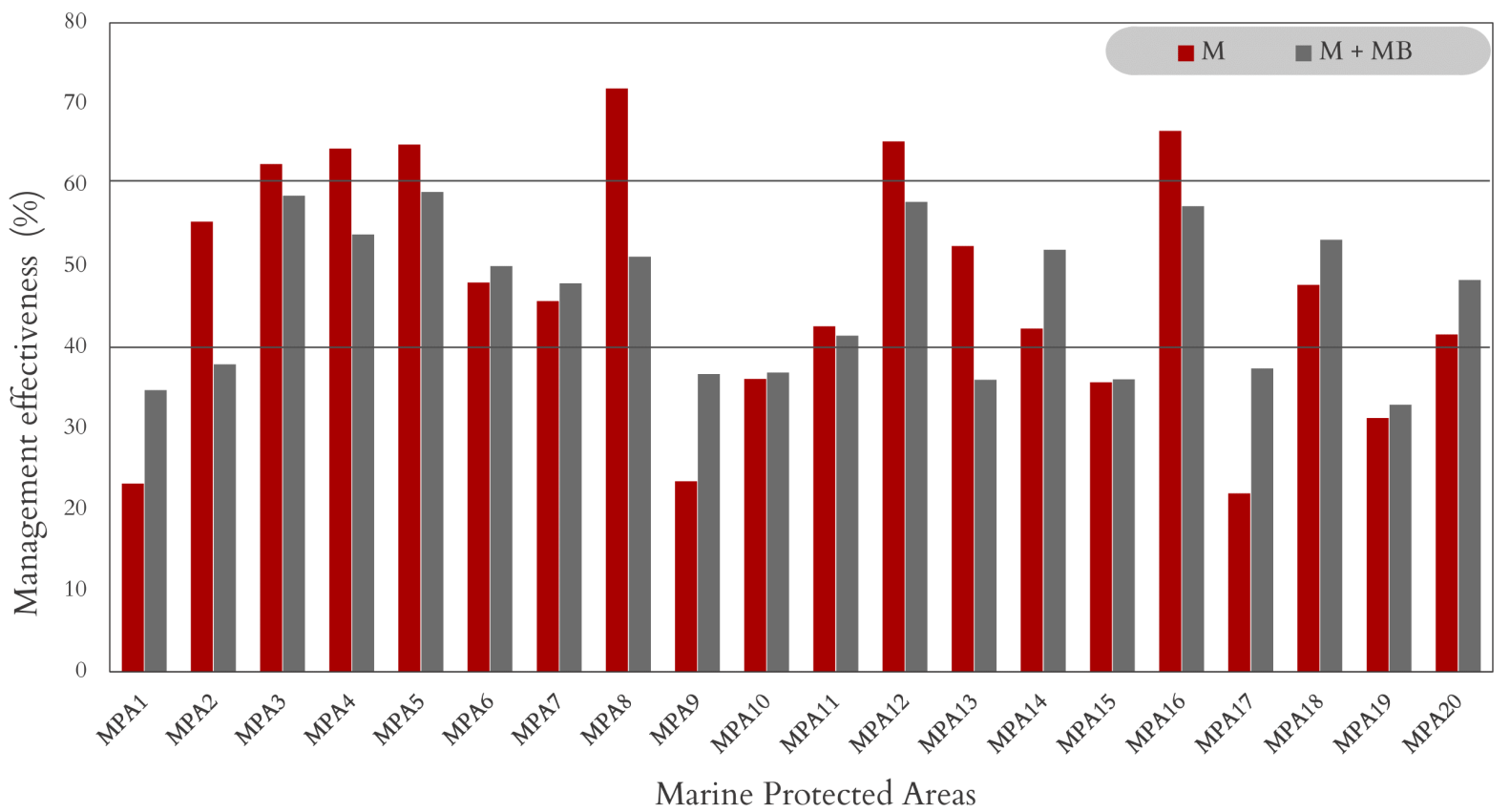

Figure 3. Management effectiveness by manager (M) and mean management effectiveness by manager (M) and management board $(\mathrm{M}+\mathrm{MB})$ for the 20 marine protected areas analyzed (below the continuous line - low management effectiveness; between the continuous and the dotted lines - medium management effectiveness; and above the dotted line - high management effectiveness).

PAs in Brazil. Meetings must be carried out at an easily accessible location, include all members of the management board, and be chaired by the manager

(Brazil 2002). Decisions made during these meetings 
Table 4. Deviance of the minimum model by verifying the effect of explanatory variable on management effectiveness by manager (M) and by management board (MB). (Gaussian Error Distribution). *Significant difference between the values of the variable.

\begin{tabular}{ccccc}
\hline \hline Response Variable & Explanatory Variable & df & Deviance/F & $\mathbf{P}$ \\
\hline \hline Effectiveness M & Management level & 1 & 233.68 & 0.34 \\
Effectiveness M & Time in the position & 1 & 0.13 & 0.98 \\
Effectiveness M & Category of protection & 1 & 8.73 & 0.85 \\
Effectiveness M & Creation year of the MPA & 1 & 416.50 & 0.20 \\
Effectiveness MB & Management level & 1 & 740.62 & $<0.01^{*}$ \\
Effectiveness MB & Time in the position & 1 & 19.09 & 0.5 \\
Effectiveness MB & Time of creation of the MB & 1 & 364.13 & $<0.01^{*}$ \\
\hline \hline
\end{tabular}

must be recorded in the minutes and made available to all council members, including new members. This favors information transparency regarding what happens in any given PA (Brazil 2002).

However, among the $20 \mathrm{MPA}$ analyzed, eight presented a significant difference and 11 presented a change in the management effectiveness category between the responses of the managers and the management boards, of which six and eight of the MPAs have deliberative management boards, respectively. Several factors could be related to this difference in the effectiveness value provided by the managers and the management boards, among which are the challenges management boards face in holding meetings. These meetings are infrequent or do not have the effective participation of council members (Nobre and Schiavetti 2013), which makes it difficult to exchange information, affecting management members' knowledge on how the MPA is actually working.

It is common for stakeholders to have different preferences regarding the performance of an MPA, like biological, economic and socio-cultural indicators, as observed by Himes (2007) in Italy. This reinforces the need to incorporate different perspectives on the areas being evaluated. In this study, although there is mismatching between manager and management board responses, with approximately $50 \%$ of the managers having lower effectiveness values (Figure 2), it is possible to observe that, from the perspective of the management board, $75 \%$ of MPAs have medium management effectiveness. This indicates that, although there are management problems, there is also a degree of success in managing these areas.

According to certain authors, the RAPPAM methodology presupposes that managers and administrators have adequate knowledge of the PA to provide sufficient information to determine the effectiveness value, and that the quality of the information provided will influence the final value obtained (Ervin 2003a, b; Cook and Hocking 2011). In the present study, problems were found during the data collection phase, whereby managers and management boards reported not having sufficient knowledge to answer all the questions, leaving some questions or modules blank or providing information that was not in alignment with the MPA's actual performance.

The problem of climate change is perceptible throughout the world because it affects the ecological functionality of reef environments, mainly due to ocean warming and acidification, which in turn causes bleaching of corals (Hoegh-Guldberg et al. 2007; Baker et al. 2008). When the RAPPAM was developed, the issue of climate change was already recognized as a threat to PAs. However, it was not seen as an issue that would affect all management aspects in these areas (Ervin and Belokurov 2010). Climate change is now even more important, as Brandão et al. (2017) have identified it as a threat for the next 5 years, being mentioned by all MPA managers within reef environments. Although there is planning for climate change, there are no inputs or processes to put such actions into practice.

The results of the present study indicate that older management boards can positively influence the effectiveness value of an MPA and contribute to its management. According to Vokou et al. (2014), in order for councils to implement effective action regarding the institutions they represent, it is necessary for local actors who are crucial for decision-making processes to be part of the council, and their distribution should be representative of the local reality. According to Federal Decree $4.340 / 02$, to carry out its functions, the PA management boards in Brazil should be as representative as possible and include active public bodies in the region and representatives of local civil society (Brazil 2002).

Furthermore, Vokou et al. (2014) also point to the issues raised by managers regarding qualification, and how council members are prepared to carry out their responsibilities. In this sense, Brazil has been developing environmental education actions, which aim to strengthen and stimulate the implementation of environmental communication and education actions, as well as promote participation and social control in 
PA creation, implementation, and management processes. This is in line with the main guidelines on the complex management of PAs (Lockwood et al. 2006).

Differences in management effectiveness between MPAs managed at federal and state levels, have also been observed in other surveys (Ogana et al. 2012), as expressed by the answers of the management boards in our study. Although both have community participation within area management, the management of all federal PAs is overseen by the Chico Mendes Institute for Biodiversity Conservation (federal institution in charge of PA management). These federal PAs have their own budget, independent of the budgets dedicated to other areas of federal environmental management (MMA 2009).

In turn, state PAs are managed under the responsibility of each state, many of which are not effectively implemented (Bernard et al. 2014), affecting their effectiveness value. These same authors point to the greater susceptibility of state PAs to local interests and political businesses when compared to federal PAs, leading to the reduction and reclassification of state PAs.

It is important to highlight some existing problems regarding the RAPPAM questionnaire, such as a lack of in-depth data analysis, as it considers only the final effectiveness value and ignores questions with negative responses. The non-existence of an "I do not know / not known" option in the questionnaire (Veenvliet and Sovinc 2009); information reliability; and the dependence on the interviewees' knowledge (Ervin 2003a; Veenvliet and Sovinc 2009), which, associated with the limited number of questionnaires applied, could affect the effectiveness value of the PA.

In addition, other problems were also found regarding application of the methodology, such as the limitations related to interviewee selection, due to the quantity of MPAs analyzed and the distance between them, which made it difficult to obtain answers for all areas. However, studies in areas that are closer together, or with the analysis of fewer MPAs, would probably not face this type of problem.

Another potential bias in online research (passive method) was also recognized, whereby only people wishing to participate in the research may respond. However, Fouladi et al. (2002) found only a small difference in the pattern of responses between questionnaires answered by the respondent (on paper) and self-administered electronic ('on-line') questionnaires. Moreover, there is a low probability of 'social desirability bias', that is, when the answer is determined by socially acceptable norms rather than the true situation (Bowling 2005). As such, we believe that the results presented here are valid for the scale of the study.

In 1992, the UN Convention on Biological Di- versity recognized the importance of engaging local communities in the formulation and implementation of conservation actions, as well as the need for environmental education and awareness (UNEP 1994). Young et al. (2012) reinforced this importance by emphasizing that the incorporation of the knowledge, skills and needs of local residents in conservation planning are important for the protection of biodiversity and conflict management.

This theme has almost reached a consensus in the literature (Glaser et al. 2010; Ferrol-Schulte et al. 2013; Jones 2014). In Brazil, the Federal Law of SNUC also addresses the issue of community participation by encouraging local populations and private organizations to establish and manage PAs through a management board (Brazil 2000).

Given the results, we suggest that not only managers, but also stakeholders with management knowledge that participate in decisions of the MPA contribute to the evaluation of management effectiveness in PAs and other areas with co-management. The approach of using a mean would be more aligned with the management situation of the PA, reducing possible inconsistencies resulting from the analysis of effectiveness using only the managers' perspectives, and helping to obtain a value closer to reality. This new reading in the method could also be carried out in other regions of the world for PAs that have a comanagement system, favoring the achievement of better results.

\section{CONCLUSION}

Among the 20 MPAs analyzed in the present study, it was observed that managers and management boards can present significant differences between their effectiveness values. Thus, it is important to conduct further research involving evaluation of the effectiveness of management boards, for example, to test the effect of the number of respondents (if there are one, two, or more members on the council) and consider the group to which the members belong (evaluating only those within civil society or those within public power separately). This information would make it possible to obtain a value that is more comparable to the reality of the area.

Additionally, there is a positive correlation between the age (creation time) of the management board and its effectiveness. It is worth highlighting a problem regarding the quality of information provided by respondents of the RAPPAM questionnaire, as the information needs to be adequate to provide sufficient data for the analysis. The verification of this information is difficult and affects the final values for management effectiveness of each MPA. Therefore, the importance of applying the questionnaire not only 
to the managers of the PA but also to other members directly involved in area management will help reduce possible inconsistencies.

\section{ACKNOWLEDGEMENT}

We would like to thank the Chico Mendes Institute for Biodiversity Preservation for their authorization to conduct research in the federal MPAs, and the state institutes and the City Hall for their support and authorization to carry out research in their respective MPAs, in addition to the managers and members of the management board themselves for agreeing to respond to the questionnaire. This study was partly financed by the Coordination for the Improvement of Higher Education Personnel (Coordenação de Aperfeiçoamento de Pessoal de Nível Superior - Brazil (CAPES)) - Finance Code 001, with the PhD scholarship to the first author, the PNPD grant provided by CAPES to the second author, and the productivity grant provided by CNPq and CAPES for the Visiting Scholarship of the last author. Finally, we would also like to thank Alexandra Maria Camilo for the English revision (Fulbright English Teaching Assistant of UESC).

\section{DATA AVAILABILITY}

The datasets generated during and/or analysed during the current study are available from the corresponding author on reasonable request.

\section{CONFLICT OF INTEREST}

The authors have no conflicts of interest to declare.

\section{CONTRIBUTION STATEMENT}

Conceived of the presented idea: C.S.B., A.S. Carried out the experiment: C.S.B, C.Z., W.D.

Carried out the data analysis: C.S.B, C.Z., W.D. J.L.T.

Wrote the first draft of the manuscript: C. S. B.

Review and final write of the manuscript: C. S. B, J.L.T.

Supervision: A.S.

\section{REFERENCES}

Almeida LT, Olímpio JLS, Pantalena AF, Almeida BS, Soares MO (2016) Evaluating ten years of management effectiveness in a mangrove protected area. Ocean Coast Manag, 125, 29-37.
Araújo JL, Bernard E (2016) Management effectiveness of a large marine protected area in Northeastern Brazil. Ocean Coast Manag, 130, 4349 .

Arnstein SR (1969) A Ladder of Citizen Participation. JAIP, 35(4), 216-224.

Babcock RC, Shears NT, Alcala AC, Barrett NS, Edgar GJ, Lafferty KD, McClanahan TR, Russ GR (2010) Decadal trends in marine reserves reveal differential rates of change in direct and indirect effects. Proc Natl Acad Sci USA, 43, 1825618261 .

Baker AC, Glynn PW, Riegl B (2008) Climate change and coral reef bleaching: an ecological assessment of the long-term impacts, recovery trends and future outlooks. Estuar Coast Shelf $S$, 80(4), 435-471.

Berkes F (1994) Co-management: Bridging the two solitudes. Northern Perspectives 22(2-3), 1820 .

Bernard E, Penna LAO, Araújo E (2014) Downgrading, Downsizing, Degazettement, and Reclassification of Protected Areas in Brazil. Conserv Biol, 28(4), 939-950.

Bowling A (2005) Mode of questionnaire administration can have serious effects on data quality. J Public Health, 27(3), 281-291.

Borrini-Feyerabend G, Dudley N, Jaeger T, Lassen B, Pathak Broome N, Phillips A, Sandwith T (2013) Governance of Protected Areas: From understanding to action Best Practice Protected Area. Guidelines Series. No 20 IUCN-WCPA, Gland, Switzerland.

Brandão CS, Malta A, Schiavetti A (2017) Temporal assessment of the management effectiveness of reef environments: The role of marine protected areas in Brazil. Ocean Coast Manag 142, 111-121.

Brazil. 1981 Lei $\mathrm{n}^{\mathrm{o}}$ 6938. Dispõe sobre a Política Nacional do Meio Ambiente, seus fins e mecanismos de formulação e aplicação, e dá outras providências. Lei n⿳0 6938 de 1981 (Accessed 18 July 2016).

Brazil. 2000 Lei $n^{\underline{0}}$ 9985. Institui o Sistema Nacional de Unidades de Conservação da Natureza. Lei n⿳0 9985 de 2000 (Accessed 02 August 2016).

Brazil. 2002 Decreto $\mathrm{n}^{\mathrm{O}}$ 4340. Regulamenta artigos da Lei no 9985, que dispõe sobre o Sistema Nacional de Unidades de Conservação da Natureza - SNUC, e dá outras providências. Decreto $\mathrm{n}^{\underline{0}} 4340$ de 2002 (Accessed 03 August 2016). 
Brandrão et al. 2021. Does the respondent's role affect the final value of management effectiveness? The case of Brazilian marine protected areas

Ethnobio Conserv 10:06

Brazil. 2006 Decreto $\mathrm{n}^{\mathrm{o}}$ 5758. Institui o Plano Estratégico Nacional de Áreas Protegidas - PNAP, seus princípios, diretrizes, objetivos e estratégias, e dá outras providências. Decreto $n^{\underline{0}} 5758$ de 2006 (Accessed 20 Julio 2016).

Campbell SJ, Kartawijaya T, Yulianto I, Prasetia R, Clifton J (2013) Co-management approaches and incentives improve management effectiveness in the Karimunjawa National Park, Indonesia. Mar Policy, 41, 72-79.

Castro CB, Santos RA, Steenbock W, Pires DO (2016) Plano de Ação Nacional para a Conservação dos Ambientes Coralíneos (PAN Corais). In: Zilberberg, C, Abrantes, DP, Marques, JA, Machado, LF, Marangoni, LFB (Eds), Conhecendo Os Recifes Brasileiros Rede de Pesquisas Coral Vivo Museu Nacional, UFRJ, Rio de Janeiro.

Cook CN, Hockings M (2011) Opportunities for improving the rigor of management effectiveness evaluations in protected areas. Conserv Lett 4(5), 372-382.

Corral LSG (2010) Caso de aplicacion de la Metodología RAPPAM a la Red de Reservas Marinas de Espana Thesis (Master en Espacios Naturales Protegidos). Fundacion Interuniversitaria Fernando Gonzalez Bernaldez, Ed Secretaría General del Mar, Madrid.

Crawley MJ (2013) The R book. John Wiley and Sons Ltd, London, UK.

Day J, Dudley N, Hockings M, Holmes G, Laffoley D, Stolton S, Wells S (2012) Guidelines for Applying the IUCN Protected Area Management Categories to Marine Protected Areas IUCN, Gland, Switzerland.

Ervin J, Belokurov V (2010) Inclusion of climate changes in the questionnaire for Rapid Assessment and Prioritization of Protected Area Management. Protected Area Management (accessed 20 November 2014).

Ervin J (2003a) WWF Rapid Assessment and Prioritization of Protected Area

Management (Rappam) Methodology WWF, Gland, Swizertland.

Ervin J, (2003b) Rapid assessment of protected area management effectiveness in four countries. BioScience, 53(9), 833-841.

Fearnside PM (2016) Brazilian politics threaten environmental policies. Science, 353(80), 746-748.

Ferrol-Schulte D, Wolff M, Ferse SCA, Glaser M
(2013) Sustainable Livelihoods Approach in tropical coastal and marine social-ecological systems: a review. Mar Pol, 42, 253-258.

Fouladi RT, McCarthy CJ, Moller NP (2002) Paperand-Pencil or Online? Evaluating Mode Effects on Measures of Emotional Functioning and Attachment Assessment, 9(2), 204-215.

Gerhardinger LC, Godoy EAS, Jones PJS, Sales G, Ferreira BP (2011) Marine Protected Dramas: The Flaws of the Brazilian National System of Marine Protected Areas. Environ Manage, 47, 630-643.

Gerhardinger LC, Gorris P, Leandra RG, Dannieli FH, Daniele AVN, Fabiano GC, Marion G, Ruben Z, Bruce CG (2018) Healing Brazil's Blue Amazon: The Role of Knowledge Networks in Nurturing Cross-Scale Transformations at the Frontlines of Ocean Sustainability Healing the Blue Amazon with Knowledge-Action Networks. Front Mar Sci, 4, 395.

Glaser M, Radjawali I, Ferse S, Glaeser B (2010) Nested participation in hierarchical societies? Lessons for social-ecological research and management Intern J. Sust Societ 2, 390-414.

Goodman PS (2003) Assessing Management Effectiveness and Setting Priorities in Protected Areas in KwaZulu-Natal. BioScience, 53(9), 843850 .

Himes AH (2007) Performance indicators in MPA management: Using questionnaires to analyze stakeholder preferences. Ocean Coast Manag 50, 329-351.

Hockings M, Leverington F, Cook C (2015) Protected area management effectiveness, in: Worboys GL, Lockwood M, Kothari A, Feary S, Pulsford I (Eds), Protected Area Governance and Management ANU Press. Canberra, pp 889-928.

Hockings M, Solton S, Dudley N (2000) Evaluation Effectiveness: a Framework for Assessing the Management of Protected Areas IUCNWCPA. Gland, Switzerland.

Hoegh-Guldberg O, Mumby PJ, Hooten AJ, Steneck RS, Greenfield P, Gomez E, Harvell CD, Sale PF, Edwards AJ, Caldeira K, Knowlton N, Eakin CM, Iglesias-Prieto R, Muthiga N, Bradbury RH, Dubi A, Hatziolos ME (2007) Coral reefs under rapid climate change and ocean acidification. Science 318(5857), 1737-1742.

Horigue V, Alino PM, White AT, Pressey, RL (2012) Marine protected area networks in the Philippines: trends and challenges for establishment 
Brandrão et al. 2021. Does the respondent's role affect the final value of management effectiveness? The case of Brazilian marine protected areas

Ethnobio Conserv 10:06

and governance. Ocean Coast Manag 64, 15-26.

Izurieta-Valery A (1997) Evaluación de la eficiencia del manejo de áreas protegidas: validación de una metodología aplicada a un subsistema de áreas protegidas y sus zonas de influencia, en el área de conservación de Osa. Costa Rica Thesis (Máster en Area de Manejo de Bosques Tropicales y Conservación de la Biodiversidad) Centro Agronómico Tropical de Investigación y Enseñanza, Turrialba.

Jones PJS (2014) Governing Marine Protected Areas: Resilience through Diversity. Oxon, New York, NY.

Kelleher G (1999) Guidelines for Marine Protected Areas IUCN. Gland, Switzerland and Cambridge, UK.

Lockwood M, Worboys GL, Kothari A (2006) Managing Protected Areas: A Global Guide. Earthscan, London.

Lu DJ, Kao CW, Chao CL (2012) Evaluating the management effectiveness of five protected areas in Taiwan using WWF's RAPPAM. Environ Manag 50(2), 272-282.

Lubchenco J, Grorud-Colvert K (2015) Making waves: the science and politics of ocean protection. Science, 350, 382-383.

Magris RA, Mills M, Fuentes MMPB, Pressey RL (2013) Analysis of progress towards a comprehensive system of marine protected areas in Brazil. Nat Conserv 11 (1), 81-87.

Marroni EV, Asmus M L (2013) Historical antecedents and local governance in the process of public policies building for coastal zone of Brazil. Ocean Coast Manage 76, 30-37.

Ministério do Meio Ambiente (MMA) (2009) Pilares para a Sustentabilidade Financeira do Sistema Nacional de Unidades de Conservação, second ed MMA/SBF/DAP, MMA, Brasília.

Ministério do Meio Ambiente (MMA) (2020) Quantidade de áreas marinhas protegidas, por esfera de gestão. https://www.mma.gov.br/areasprotegidas/unidades-de-conservacao/sistema-

nacional-de-ucs-snuc.html (accessed 21 Julio 2020).

Mumby PJ, Dahlgren CP, Harborne AR, Kappel CV, Micheli F, Brumbaugh DR, Holmes KE, Mendes JM, Broad K, Sanchirico JN, Buch K, Box S, Stoffle RW, Gill AB (2006) Fishing, Trophic Cascades, and the Process of Grazing on Coral. Reefs Science, 311(5757):98-101.
Nobre DM, Schiavetti A (2013) Acordos de Pesca, Governança e Conselho Deliberativo de Reserva Extrativista: Caso da Resex de Cassurubá, Caravelas, Bahia, Brasil. Bol Inst Pesca 39(4):445 - 455 .

Nobre DM, Alarcon DT, Cinti A, Schiavetti, A (2017) Governance of the Cassurubá Extractive Reserve, Bahia State, Brazil: An analysis of strengths and weaknesses to inform policy. Mar Policy, 77, 44-55.

Ogana CA, Drumond MA, Ferreira MN (2012) (Org) Management Effectiveness of Brazilian Federal Protected Areas: Results of 2010 WWFBRASIL, ICMBio, Brasília.

Oliveira-Júnior JG, Ladle RJ, Correia R, Batista VS (2016) Measuring what matters - Identifying indicators of success for Brazilian marine protected areas. Mar Policy, 74, 91-98.

Palumbi S R (2004) Marine reserves and ocean neighborhoods: the spatial scale of marine populations and their management. Ann Rev Environ Resour, 29:31-68.

Pinheiro HT, Di Dario F, Gerhardinger LC, de Melo MRS, De Moura RL, Reis RE, Vieira F, Zuanon J, Rocha LA (2015) Brazilian aquatic biodiversity in peril. Science, 350, 1043-1044.

R Development Team (2016) R: A language and environment for statistical computing $\mathbf{R}$ Foundation for Statistical Computing [Internet] $\mathbf{R}$ Foundation for Statistical Computing, Viena, Austria.

Santos CZ, Schiavetti A (2014) Assessment of the management in Brazilian Marine Extractive Reserves. Ocean Coast Manage, 93, 26-36.

Schiavetti A, Manz J, Santos CZ, Magro TC, Pagani MI (2013) Marine Protected Areas in Brazil: An ecological approach regarding the large marine ecosystems. Ocean Coast Manage, 76, 96-104.

Soares MO, Lucas CC (2018) Towards large and remote protected areas in the South Atlantic Ocean: St Peter and St Paul's Archipelago and the Vitória-Trindade Seamount Chain. Mar Pol, 93, 101-103.

UNEP (1994) Convention on Biological Diversity Text and Annexes United Nations Environment Programme, Châtelaine.

UNEP-WCMC and IUCN (2017) Protected Planet Report 2017 Cambridge, UK and Gland, Switzerland: UNEP-WCMC and IUCN.

Vasconcellos M, Diegues AC, Kalikoski DC (2011) 
Coastal fisheries of Brazil. In. Salas S, Chuenpagdee R, Charles A, Seijo JC Coastal fisheries of Latin America and the Caribbean FAO, Rome, 73116.

Vasconcelos L, Pereira MJR, Caser U, Goncalves G, Silva F, Sa R (2013) MARGov-setting the ground for the governance of marine protected areas. Ocean Coast Manag 72, 46-53.

Veenvliet JK, Sovinc A (2009) Protected area management effectiveness in Slovenia, Final report of the RAPPAM analysis WWF, Slovenia.

Venter O, Fuller R A, Segan D B, Carwardine J, Brooks T, Butchart S H M, Moritz C (2014) Targeting global protected area expansion for im- periled biodiversity. PLoS Biology, 12(6).

Vokou D, Dimitrakopoulos PG, Damialis A, Pantis JD (2014) Ten years of co-management in Greek protected areas: An evaluation. Biodivers Conserv 23, 2833-2855.

Weeks R, Jupiter SD (2013) Adaptive Comanagement of a Marine Protected Area Network in Fiji. Conserv Biol 27(6), 1234-1244.

Received: 01 June 2020

Accepted: 29 July 2020

Available: 07 October 2020 


\section{Additional Files}

\section{Add File 1}

\section{PAN Coral Reef Effectiveness Questionnaire GUIDELINES FOR ANSWERING THIS QUESTIONNAIRE}

Modules 3 to 20 have the following options to each question: Yes, Mostly Yes, Mostly No, and No, considering that the respondent must choose the option that best describes the situation in the conservation unit.

The questionnaire should be answered by the manager of the conservation unit and 2 members of the management council, 1 of the government, and 1 civilian.

This questionnaire will be used for the development of the doctoral project entitled "Efetividade das Unidades de Conservação Marinhas que protegem ambientes recifais no litoral brasileiro", conducted by Camila dos Santos Brandão, a student at the Universidade Estadual de Santa Cruz - UESC, with the approval of Sisbio (Authorisation No. 45079-8).

The data collected here will be used solely for research, to prepare reports for Sisbio, and for the conservation units that request these data.

The names of the persons who provided the information will be safeguarded, and will only be used to control the research.

\section{Assessment of the Effectiveness of Marine Conservation Units GENERAL INFORMATION OF THE CONSERVATION UNIT}

\section{PROFILE}

a) Name of the conservation unit:

b) Date of creation of the conservation unit:

c) Area of the conservation unit (ha):

d) Percentage of terrestrial area of the conservation unit (\%):

e) Full name of the person responsible for this information:

f) Position of the person responsible for the information: ( ) Manager ( ) Management council

g) Time working in this position:

h) Date of completion of the questionnaire:

i) Number of workers at the conservation unit: fully employed: temporary: volunteers:

j) Number of outsourced workers:

l) Number of people from formal partnerships: 


\section{CONTEXT}

\begin{tabular}{|l|l|l|l|l|}
\hline 3. BIOLOGICAL IMPORTANCE & $\mathbf{Y}$ & $\mathbf{M} / \mathbf{Y}$ & $\mathbf{M} / \mathbf{N}$ & $\mathbf{N}$ \\
\hline $\begin{array}{l}\text { a) The CU contains all the possible species on the Brazilian list } \\
\text { or on the state lists of endangered species. }\end{array}$ & & & \\
\hline $\begin{array}{l}\text { b) The CU contains a significant number of species that are en- } \\
\text { dangered, overexploited, threatened by overexploitation, and/or } \\
\text { reduced by various pressures. }\end{array}$ & & & & \\
\hline $\begin{array}{l}\text { c) The CU contains all the possible species that represent the } \\
\text { coastal biodiversity of Brazil. }\end{array}$ & & & \\
\hline d) The CU has significant levels of endemism of coral reef species. & & & & \\
\hline e) The CU exerts a critical landscape function. & & & & \\
\hline $\begin{array}{l}\text { f) The CU contains a full range of representatives of all the species } \\
\text { associated with the present ecosystems. }\end{array}$ & & & \\
\hline $\begin{array}{l}\text { g) The CU system is highly representative of the marine protected } \\
\text { areas of Brazil. }\end{array}$ & & & & \\
\hline $\begin{array}{l}\text { h) The CU supports minimal viable populations of coral reef } \\
\text { species. }\end{array}$ & & & & \\
\hline i) The CU maintains the historical patterns of structural diversity. & & & & \\
\hline $\begin{array}{l}\text { j) The CU protects ecosystems in an area that has declined sig- } \\
\text { nificantly. }\end{array}$ & & & \\
\hline
\end{tabular}

NOTE: If a question does not apply, if it cannot be answered, or if there is some special feature, PLEASE ENTER THIS INFORMATION HERE! 


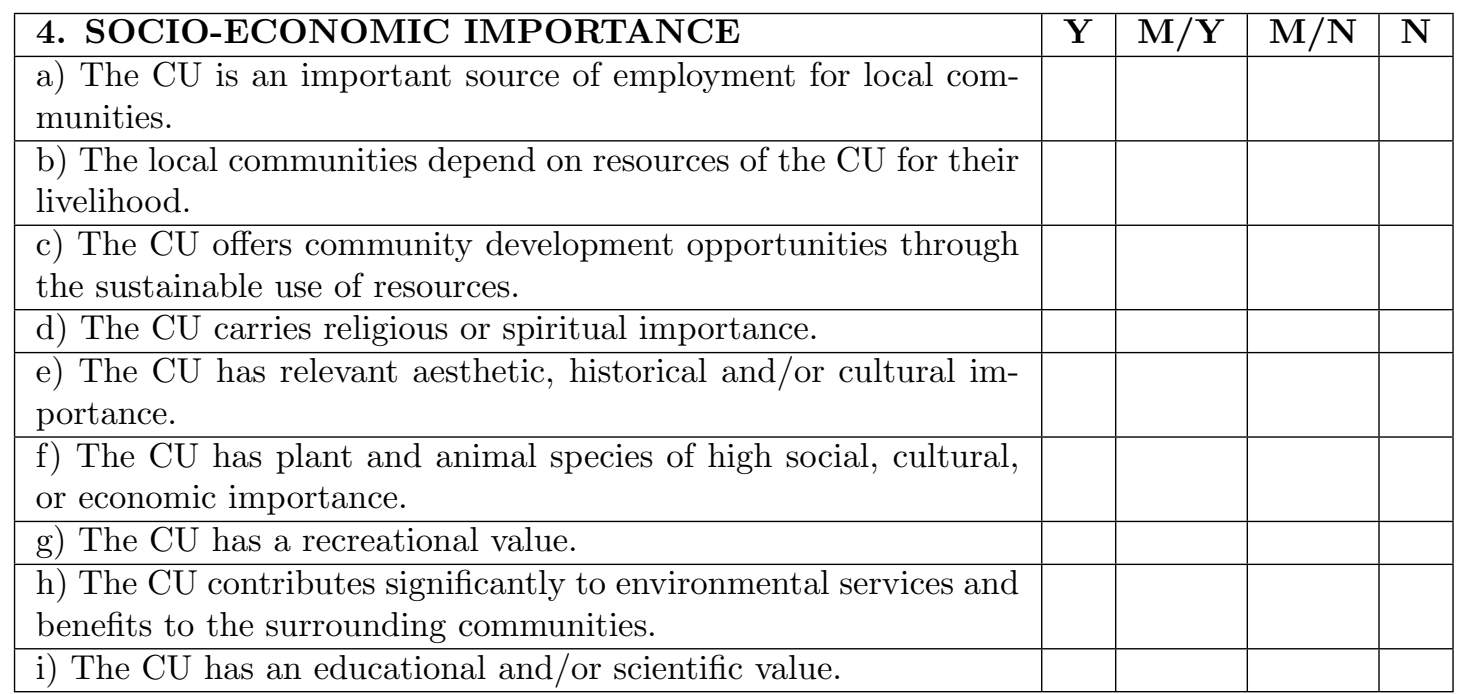

NOTE: If a question does not apply, if it cannot be answered, or if there is some special feature, PLEASE ENTER THIS INFORMATION HERE!

\begin{tabular}{|l|l|l|l|l|}
\hline 5. OVERALL VULNERABILITY & Y & M/Y & M/N & N \\
\hline a) Any illegal activities at the CU are difficult to monitor. & & & & \\
\hline b) The application of legal instruments is low in the region. & & & & \\
\hline c) It is difficult to control any illegal activities inside the CU. & & & & \\
\hline $\begin{array}{l}\text { d) Cultural practices, beliefs, and traditional uses are in conflict } \\
\text { with the goals of the CU. }\end{array}$ & & & \\
\hline e) The CU resources have a high market value. & & & & \\
\hline f) The conservation unit is easily accessible for illegal activities. & & & & \\
\hline g) There is a high demand for the natural resources of the CU. & & & & \\
\hline $\begin{array}{l}\text { h) Management of the CU is suffering pressure to create actions } \\
\text { that are contrary to its objectives. }\end{array}$ & & & & \\
\hline i) It is difficult to hire employees for the CU. & & & & \\
\hline j) It is difficult to retain the team at the CU. & & & & \\
\hline l) The local community has a negative perception of the CU. & & & & \\
\hline
\end{tabular}

NOTE: If a question does not apply, if it cannot be answered, or if there is some special feature, PLEASE ENTER THIS INFORMATION HERE! 


\begin{tabular}{|l|l|l|l|l|}
\hline 6. VULNERABILITY TO CLIMATE CHANGE & $\mathbf{Y}$ & $\mathbf{M}$ Y & $\mathbf{M} / \mathbf{N}$ & $\mathbf{N}$ \\
\hline $\begin{array}{l}\text { a) Any existing threats will exacerbate the effects of climate } \\
\text { change. }\end{array}$ & & & \\
\hline b) The area is susceptible to rising sea levels. & & & & \\
\hline $\begin{array}{l}\text { c) The area contains species that are particularly susceptible to } \\
\text { increased temperature changes. }\end{array}$ & & & \\
\hline $\begin{array}{l}\text { d) The area contains species that are on the edge of their geo- } \\
\text { graphical distribution (North, South, East, or West). }\end{array}$ & & & \\
\hline $\begin{array}{l}\text { e) The area is susceptible to chemical changes associated with } \\
\text { climate change (for example, acidification). }\end{array}$ & & & \\
\hline $\begin{array}{l}\text { f) The area plays a fundamental role in the conservation of species } \\
\text { under climate change scenarios. }\end{array}$ & & & & \\
\hline
\end{tabular}

NOTE: If a question does not apply, if it cannot be answered, or if there is some special feature, PLEASE ENTER THIS INFORMATION HERE!

\section{PLANNING}

\begin{tabular}{|c|c|c|c|c|}
\hline 7. GOALS & $\mathbf{Y}$ & $\mathbf{M} / \mathbf{Y}$ & $\mathbf{M} / \mathbf{N}$ & $\mathbf{N}$ \\
\hline $\begin{array}{l}\text { a) The goals of the CU include the protection and conservation of } \\
\text { biodiversity. }\end{array}$ & & & & \\
\hline $\begin{array}{l}\text { b) The specific goals related to biodiversity are clearly expressed } \\
\text { in the CU planning instruments. }\end{array}$ & & & & \\
\hline $\begin{array}{l}\text { c) The management instruments are consistent with the goals of } \\
\text { the CU. }\end{array}$ & & & & \\
\hline $\begin{array}{l}\text { d) The workers and administrators of the CU understand the goals } \\
\text { and policies of the CU. }\end{array}$ & & & & \\
\hline $\begin{array}{l}\text { e) The management council of the CU understands the goals and } \\
\text { policies of the CU. }\end{array}$ & & & & \\
\hline f) The local communities support the goals of the CU. & & & & \\
\hline g) Public use is incompatible with the goals of the CU. & & & & \\
\hline
\end{tabular}

NOTE: If a question does not apply, if it cannot be answered, or if there is some special feature, PLEASE ENTER THIS INFORMATION HERE!

\begin{tabular}{|l|l|l|l|l|}
\hline 8. LEGAL SUPPORT & $\mathbf{Y}$ & $\mathbf{M} / \mathbf{Y}$ & $\mathbf{M} / \mathbf{N}$ & $\mathbf{N}$ \\
\hline a) The CU and its natural resources have legal backing. & & & & \\
\hline b) The land tenure is regularised. & & & & \\
\hline c) Demarcation and boundary signalling of the CU are suitable. & & & & \\
\hline $\begin{array}{l}\text { d) The human and financial resources are adequate for the critical } \\
\text { protection actions. }\end{array}$ & & & \\
\hline e) There is legal support for conflict management. & & & & \\
\hline
\end{tabular}

NOTE: If a question does not apply, if it cannot be answered, or if there is some special feature, PLEASE ENTER THIS INFORMATION HERE! 


\begin{tabular}{|l|l|l|l|l|}
\hline 9. DESIGN AND PLANNING OF THE AREA & Y & M/Y & M/N & N \\
\hline a) The location of the CU is consistent with its goals. & & & & \\
\hline $\begin{array}{l}\text { b) The design of the CU favours biodiversity conservation and/or } \\
\text { socio-cultural and economic aspects. }\end{array}$ & & & \\
\hline $\begin{array}{l}\text { c) The design and category of the CU were defined in a partici- } \\
\text { patory process. }\end{array}$ & & & \\
\hline d) CU zoning is appropriate for achieving the goals. & & & \\
\hline $\begin{array}{l}\text { e) Land/Sea use in the immediate surroundings enable the effec- } \\
\text { tive management of the CU. }\end{array}$ & & & \\
\hline f) The CU is part of a larger management zoning plan. & & & \\
\hline $\begin{array}{l}\text { g) The category of the CU is suited to the natural features and } \\
\text { use of the area. }\end{array}$ & & & \\
\hline $\begin{array}{l}\text { i) The limits of the CU are respected by all users (fishing commu- } \\
\text { nity, tourists, diving groups). }\end{array}$ & & & \\
\hline $\begin{array}{l}\text { j) The CU has ecological connectivity or continuity with other } \\
\text { CUs. }\end{array}$ & & & \\
\hline
\end{tabular}

NOTE: If a question does not apply, if it cannot be answered, or if there is some special feature, PLEASE ENTER THIS INFORMATION HERE!

\begin{tabular}{|l|l|l|l|l|}
\hline 10. PLANNING AND ADAPTATION TO CLIMATE & $\mathbf{Y}$ & $\mathbf{M} / \mathbf{Y}$ & $\mathbf{M} / \mathbf{N}$ & $\mathbf{N}$ \\
CHANGE & & & \\
\hline $\begin{array}{l}\text { a) The workers and administrators of the CU understand the im- } \\
\text { portance and the implications of adapting to climate change. }\end{array}$ & & & & \\
\hline $\begin{array}{l}\text { b) Climate-related conflicts are understood and proactively ad- } \\
\text { dressed. }\end{array}$ & & & & \\
\hline $\begin{array}{l}\text { c) The design and demarcation of the CU minimises climate- } \\
\text { related impacts. }\end{array}$ & & & \\
\hline $\begin{array}{l}\text { d) The design and demarcation of the CU optimises and improves } \\
\text { adaptation of the species and the ecosystem. }\end{array}$ & & & & \\
\hline
\end{tabular}

NOTE: If a question does not apply, if it cannot be answered, or if there is some special feature, PLEASE ENTER THIS INFORMATION HERE!

\section{INPUTS}

\begin{tabular}{|l|l|l|l|l|}
\hline 11. HUMAN RESOURCES & Y & M/Y & M/N & N \\
\hline a) There are enough employees to manage the area effectively. & & & & \\
\hline $\begin{array}{l}\text { b) The employees have skills that allow them to develop critical } \\
\text { or priority management activities. }\end{array}$ & & & & \\
\hline $\begin{array}{l}\text { c) The team is offered training and development opportunities to } \\
\text { meet the needs of the CU. }\end{array}$ & & & & \\
\hline d) There is a periodic assessment of performance and progress. & & & & \\
\hline $\begin{array}{l}\text { e) The working conditions allow the team to meet the goals of the } \\
\text { CU. }\end{array}$ & & & & \\
\hline
\end{tabular}

NOTE: If a question does not apply, if it cannot be answered, or if there is some special feature, PLEASE ENTER THIS INFORMATION HERE! 


\begin{tabular}{|l|l|l|l|l|}
\hline 12. COMMUNICATION AND INFORMATION & $\mathbf{Y}$ & $\mathbf{M} / \mathbf{Y}$ & $\mathbf{M} / \mathbf{N}$ & $\mathbf{N}$ \\
\hline $\begin{array}{l}\text { a) There are appropriate means of communication between em- } \\
\text { ployees in the field and at the office. }\end{array}$ & & & \\
\hline $\begin{array}{l}\text { b) The existing ecological and socioeconomic information is ap- } \\
\text { propriate for management planning. }\end{array}$ & & & \\
\hline c) There are adequate means for data collection. & & & \\
\hline d) There are adequate systems for data processing and analysis. & & & & \\
\hline $\begin{array}{l}\text { f) There is effective communication of the CU with the local com- } \\
\text { munities. }\end{array}$ & & & \\
\hline $\begin{array}{l}\text { g) There is effective communication with the various administra- } \\
\text { tions that affect/participate in the management of the area. }\end{array}$ & & & & \\
\hline
\end{tabular}

NOTE: If a question does not apply, if it cannot be answered, or if there is some special feature, PLEASE ENTER THIS INFORMATION HERE!

\begin{tabular}{|c|c|c|c|c|}
\hline \multirow{2}{*}{$\begin{array}{l}\text { 13. INFRASTRUCTURE } \\
\text { a) The transport infrastructure is appropriate to meet the goals } \\
\text { of the CU. }\end{array}$} & $\mathbf{Y}$ & $\mathbf{M} / \mathbf{Y}$ & $\mathbf{M} / \mathbf{N}$ & $\mathbf{N}$ \\
\hline & & & & \\
\hline $\begin{array}{l}\text { b) The work equipment (field and office) is appropriate to meet } \\
\text { the goals of the CU. }\end{array}$ & & & & \\
\hline $\begin{array}{l}\text { c) The land and sea infrastructure allows the workers to perform } \\
\text { critical management activities. }\end{array}$ & & & & \\
\hline $\begin{array}{l}\text { d) The maintenance and care of equipment are adequate to ensure } \\
\text { long-term use. }\end{array}$ & & & & \\
\hline $\begin{array}{l}\text { e) There is an infrastructure for visitors (interpretation centre, } \\
\text { museum, information centre). }\end{array}$ & & & & \\
\hline $\begin{array}{l}\text { f) The infrastructure for visitors is adequate for the volume of } \\
\text { visitors. }\end{array}$ & & & & \\
\hline
\end{tabular}

NOTE: If a question does not apply, if it cannot be answered, or if there is some special feature, PLEASE ENTER THIS INFORMATION HERE!

\begin{tabular}{|c|c|c|c|c|}
\hline 14. FINANCIAL RESOURCES & $\mathbf{Y}$ & $\mathbf{M} / \mathbf{Y}$ & $\mathbf{M} / \mathbf{N}$ & $\mathbf{N}$ \\
\hline a) The current budget meets the management needs of the CU. & & & & \\
\hline $\begin{array}{l}\text { b) The financial resources of the last } 5 \text { years were sufficient to } \\
\text { meet the goals of the CU. }\end{array}$ & & & & \\
\hline $\begin{array}{l}\text { c) Financial resources for the next } 5 \text { years have been estimated to } \\
\text { meet the goals of the } \mathrm{CU} \text {. }\end{array}$ & & & & \\
\hline $\begin{array}{l}\text { d) The financial management practices promote the efficient man- } \\
\text { agement of the CU. }\end{array}$ & & & & \\
\hline $\begin{array}{l}\text { e) The allocation of resources complies with the priorities and } \\
\text { goals of the CU. }\end{array}$ & & & & \\
\hline $\begin{array}{l}\text { f) The financial forecast for the conservation unit in the long term } \\
\text { is stable. }\end{array}$ & & & & \\
\hline $\begin{array}{l}\text { g) The conservation unit is capable of attracting external re- } \\
\text { sources. }\end{array}$ & & & & \\
\hline $\begin{array}{l}\text { h) The CU generates resources with other practices (ticket sales, } \\
\text { contribution of NGOs, taxes, fees). }\end{array}$ & & & & \\
\hline $\begin{array}{l}\text { i) The resources obtained from the various practices remain at the } \\
\text { CU. }\end{array}$ & & & & \\
\hline
\end{tabular}

NOTE: If a question does not apply, if it cannot be answered, or if there is some special feature, PLEASE ENTER THIS INFORMATION HERE! 


\begin{tabular}{|c|c|c|c|c|}
\hline 15. INPUTS TO CLIMATE CHANGE & $\mathbf{Y}$ & $\mathbf{M} / \mathbf{Y}$ & $\mathbf{M} / \mathbf{N}$ & $\mathbf{N}$ \\
\hline $\begin{array}{l}\text { a) The staff has the appropriate skills and knowledge to manage } \\
\text { the climate change adaptation and mitigation. }\end{array}$ & & & & \\
\hline $\begin{array}{l}\text { b) Existing data on the potential impacts of climate change are } \\
\text { suitable for management planning. }\end{array}$ & & & & \\
\hline $\begin{array}{l}\text { c) The role of CUs in climate change adaptation and mitigation } \\
\text { is appropriately communicated. }\end{array}$ & & & & \\
\hline $\begin{array}{l}\text { d) Equipment and installations are suitable for monitoring the } \\
\text { impacts of climate change. }\end{array}$ & & & & \\
\hline $\begin{array}{l}\text { e) The area has current financial mechanisms related to the cli- } \\
\text { mate (for example, REDD }+ \text {, mitigation funds). }\end{array}$ & & & & \\
\hline
\end{tabular}

NOTE: If a question does not apply, if it cannot be answered, or if there is some special feature, PLEASE ENTER THIS INFORMATION HERE!

\section{PROCESSES}

\begin{tabular}{|c|c|c|c|c|}
\hline 16. PLANNING & $\mathbf{Y}$ & $\mathbf{M} / \mathbf{Y}$ & $\mathbf{M} / \mathbf{N}$ & $\mathbf{N}$ \\
\hline a) There is a current and comprehensive management plan. & & & & \\
\hline $\begin{array}{l}\text { b) There is an inventory of natural and cultural resources that is } \\
\text { suitable for the management of the CU. }\end{array}$ & & & & \\
\hline $\begin{array}{l}\text { c) There is an analysis and a strategy to address the threats and } \\
\text { pressures of CU. }\end{array}$ & & & & \\
\hline $\begin{array}{l}\text { d) There is a detailed annual work plan with specific goals to meet } \\
\text { the management objectives. }\end{array}$ & & & & \\
\hline $\begin{array}{l}\text { e) The results of the research, monitoring, and traditional knowl- } \\
\text { edge are used routinely in planning. }\end{array}$ & & & & \\
\hline $\begin{array}{l}\text { f) There is coastal management that is planned and integrated to } \\
\text { land-use in the immediate surroundings of the CU. }\end{array}$ & & & & \\
\hline g) There is public use planning. & & & & \\
\hline $\begin{array}{l}\text { h) There is updated mapping (GIS) to support management ac- } \\
\text { tivities. }\end{array}$ & & & & \\
\hline $\begin{array}{l}\text { i) There is a monitoring plan that periodically oversees manage- } \\
\text { ment of the CU. }\end{array}$ & & & & \\
\hline $\begin{array}{l}\text { j) There is an education and awareness programme tied to man- } \\
\text { agement goals. }\end{array}$ & & & & \\
\hline
\end{tabular}

NOTE: If a question does not apply, if it cannot be answered, or if there is some special feature, PLEASE ENTER THIS INFORMATION HERE!

\begin{tabular}{|c|c|c|c|c|}
\hline 17. DECISION-MAKING PROCESS & $\mathbf{Y}$ & $\mathbf{M} / \mathbf{Y}$ & $\mathbf{M} / \mathbf{N}$ & $\mathbf{N}$ \\
\hline a) There is a clear internal organisation of the management team. & & & & \\
\hline b) Decision-making in management is transparent. & & & & \\
\hline $\begin{array}{l}\text { c) The CU regularly collaborates with partners, local communities } \\
\text { and other organisations. }\end{array}$ & & & & \\
\hline $\begin{array}{l}\text { d) The local communities effectively participate in the manage- } \\
\text { ment of the CU, contributing to the decision-making process. }\end{array}$ & & & & \\
\hline e) There is a well-established and effective council. & & & & \\
\hline $\begin{array}{l}\text { f) There is effective coordination between the CU and related } \\
\text { organs and entities. }\end{array}$ & & & & \\
\hline $\begin{array}{l}\text { g) There is positive communication and cooperation of the travel } \\
\text { agencies in relation to management of the CU. }\end{array}$ & & & & \\
\hline
\end{tabular}

NOTE: If a question does not apply, if it cannot be answered, or if there is some special feature, PLEASE ENTER THIS INFORMATION HERE! 


\begin{tabular}{|c|c|c|c|c|}
\hline $\begin{array}{l}\text { 18. RESEARCH, ASSESSMENT, AND MONITOR- } \\
\text { ING. }\end{array}$ & $\mathbf{Y}$ & $\mathbf{M} / \mathbf{Y}$ & $\mathbf{M} / \mathbf{N}$ & $\mathbf{N}$ \\
\hline $\begin{array}{l}\text { a) The impact of the legal activities of the } \mathrm{CU} \text { is monitored and } \\
\text { accurately recorded. }\end{array}$ & & & & \\
\hline $\begin{array}{l}\text { b) The impact of the illegal activities of the CU is monitored and } \\
\text { accurately recorded. }\end{array}$ & & & & \\
\hline $\begin{array}{l}\text { c) The impacts of public use are accurately monitored and duly } \\
\text { recorded. }\end{array}$ & & & & \\
\hline $\begin{array}{l}\text { d) Research on ecological issues is consistent with the needs of the } \\
\text { CU. }\end{array}$ & & & & \\
\hline $\begin{array}{l}\text { e) Research on socioeconomic issues is consistent with the needs } \\
\text { of the CU. }\end{array}$ & & & & \\
\hline $\begin{array}{l}\text { f) The CU and local communities have regular access to informa- } \\
\text { tion from surveys conducted at the CU. }\end{array}$ & & & & \\
\hline g) The CU team has access to recent scientific knowledge. & & & & \\
\hline $\begin{array}{l}\text { h) The critical needs for research and monitoring are identified } \\
\text { and given priority. }\end{array}$ & & & & \\
\hline $\begin{array}{l}\text { i) The results of research and monitoring are regularly incorpo- } \\
\text { rated into planning and allow adaptive management of the CU. }\end{array}$ & & & & \\
\hline
\end{tabular}

NOTE: If a question does not apply, if it cannot be answered, or if there is some special feature, PLEASE ENTER THIS INFORMATION HERE!

\begin{tabular}{|c|c|c|c|c|}
\hline 19. CLIMATE CHANGE PROCESSES & $\mathbf{Y}$ & $\mathbf{M} / \mathbf{Y}$ & $\mathbf{M} / \mathbf{N}$ & $\mathbf{N}$ \\
\hline $\begin{array}{l}\text { a) The management plan explicitly incorporates the likely impacts } \\
\text { of climate change. }\end{array}$ & & & & \\
\hline $\begin{array}{l}\text { b) There is a review and a strategy to address climate change- } \\
\text { related threats. }\end{array}$ & & & & \\
\hline $\begin{array}{l}\text { c) Decisions regarding the compensations of biodiversity and cli- } \\
\text { mate management are transparent. }\end{array}$ & & & & \\
\hline $\begin{array}{l}\text { d) The impacts of climate change are clearly recorded and com- } \\
\text { pared with basic information. }\end{array}$ & & & & \\
\hline $\begin{array}{l}\text { e) Research on key climate-related issues is consistent with the } \\
\text { impacts of climate change on the CU. }\end{array}$ & & & & \\
\hline
\end{tabular}

NOTE: If a question does not apply, if it cannot be answered, or if there is some special feature, PLEASE ENTER THIS INFORMATION HERE! 


\section{RESULTS}

\begin{tabular}{|c|c|c|c|c|}
\hline $\begin{array}{l}\text { 20. RESULTS (In the last two years, the following actions } \\
\text { were consistent with the threats and pressures, the goals } \\
\text { of the CU, the annual work plan, and the existing and } \\
\text { potential impacts of climate change) }\end{array}$ & $\mathbf{Y}$ & $\mathbf{M} / \mathbf{Y}$ & $\mathbf{M} / \mathbf{N}$ & $\mathbf{N}$ \\
\hline $\begin{array}{l}\text { a) The CU ensured the prevention and detection of threats, and } \\
\text { the application of relevant laws. }\end{array}$ & & & & \\
\hline $\begin{array}{l}\text { b) The CU ensured the recovery of areas and preventive/corrective } \\
\text { actions adapted to its needs. }\end{array}$ & & & & \\
\hline $\begin{array}{l}\text { c) The CU performed the management of wildlife, habitat or nat- } \\
\text { ural resources tailored to its needs. }\end{array}$ & & & & \\
\hline d) The CU held campaigns to divulge information to society. & & & & \\
\hline e) The CU controlled the number of visitors according to its needs. & & & & \\
\hline f) The CU implemented and maintained its infrastructure. & & & & \\
\hline $\begin{array}{l}\text { g) The CU performed management planning and prepared inven- } \\
\text { tories. }\end{array}$ & & & & \\
\hline h) The CU supervised and assessed staff performance. & & & & \\
\hline i) The CU provided training and human resources development. & & & & \\
\hline $\begin{array}{l}\text { j) The CU supported the organisation, training, and development } \\
\text { of local units and the council. }\end{array}$ & & & & \\
\hline 1) Research was conducted at the CU in accordance with its goals. & & & & \\
\hline m) The results of management were monitored. & & & & \\
\hline n) The CU provided environmental education actions. & & & & \\
\hline $\begin{array}{l}\text { o) The actions to prevent climatic threats were sufficient to min- } \\
\text { imise related threats, such as invasive species. }\end{array}$ & & & & \\
\hline $\begin{array}{l}\text { p) The actions to restore key ecosystems were sufficient to min- } \\
\text { imise climate impacts and increase resilience. }\end{array}$ & & & & \\
\hline $\begin{array}{l}\text { q) The habitat or wildlife management actions were sufficient to } \\
\text { minimise potential climate impacts. }\end{array}$ & & & & \\
\hline $\begin{array}{l}\text { r) The activities to raise awareness on the importance of the CU in } \\
\text { the mitigation and adaptation of climate change were appropriate. }\end{array}$ & & & & \\
\hline $\begin{array}{l}\text { s) Infrastructure development actions did not increase or aggra- } \\
\text { vate climate-related impacts. }\end{array}$ & & & & \\
\hline $\begin{array}{l}\text { t) The management planning actions were sufficient to resolve } \\
\text { existing climate change impacts. }\end{array}$ & & & & \\
\hline $\begin{array}{l}\text { u) Staff training and results related to climate change were suffi- } \\
\text { cient to achieve the main goals. }\end{array}$ & & & & \\
\hline $\begin{array}{l}\text { v) The research and monitoring of results on climate change were } \\
\text { consistent with the level of climate threats. }\end{array}$ & & & & \\
\hline
\end{tabular}

NOTE: If a question does not apply, if it cannot be answered, or if there is some special feature, PLEASE ENTER THIS INFORMATION HERE! 